\title{
PENGEMBANGAN MODEL PEMBELAJARAN MATEMATIKA KNISLEY BERBASIS BRAINSTORMING MATERI STATISTIKA SMA KELAS X
}

\author{
Lilik Mindarti ${ }^{1}$, Sunismi ${ }^{2}$, Anies Fuady ${ }^{3}$ \\ ${ }^{1,2,3)}$ Program Studi Pendidikan Matematika FKIP Universitas Islam Malang \\ ${ }^{1)}$ lilikmindarti@gmail.com, ${ }^{2)}$ sunismiunisma@yahoo.com, ${ }^{3)}$ fuadyanies@gmail.com
}

\begin{abstract}
The aim of this development is to produce mathemathics Kinsley learning model of Brainstroming-based Statistics of the Tenth grade Senior High School. This study employed research and development design in which the researcher developed a mathematics Kinsley learning model of brainstorming-based statistics for the tenth grade senior high school students. This study operated the model development of Plomp with 4 developmental steps as follows 1) Preliminary Insvestigation, 2) Design, 3) Realisation, 4) Test, evaluation, and Revision. The instruments used were validation sheet, responses questionnaire, and observation sheet. 35 students of the class X IPA 4 SMAN 3 Malang were involved in this study. The results of this study were validated by two balidators; expert and practitionaire validators. User responses use to evaluate practicion of product. The validity from validators group and user obtain the score at 3,34, this mean the validity is significant. Then the result of development of mathemathics Knisley learning model of Brainstorming can be implementation on mathematic teaching on the class conventionally.
\end{abstract}

Keywords: develophing, mathemathics Knisley leraning model, brainstorming, statistics

\section{PENDAHULUAN}

Pendidikan merupakan salah satu kebutuhan dan usaha untuk menyiapkan peserta didik dalam menghadapi perubahan lingkungan hidup yang semakin pesat. Kurikulum 2013 yang ada lebih menekankan kepada kompetensi berbasis sikap, keterampilan, dan pengetahuan. Sesuai dengan pernyataan tersebut maka mata pelajaran matematika harus mempunyai kontribusi yang sesuai dengan kurikulum 2013, yakni berupa desain pembelajaran yang meningkatkan aktivitas peserta didik. Salah satu solusi yang dapat dipertimbangkan untuk digunakan dalam proses pembelajaran matematika adalah model pembelajaran matematika Knisley. Siklus dari model pembelajaran matematika Knisley ini sangat menarik, karena tingkat keaktifan dari pendidik dan peserta didik saling bergantian (Asih, 2013:26)

Selain model pembelajaran, proses pembelajaran juga harus ditunjang dengan metode pembelajaran yang sesuai dengan model tersebut. Metode brainstorming merupakan teknik mengajar yang dilaksanakan oleh pendidik dengan cara melontarkan masalah di kelas, kemudian peserta didik menjawab, menyatakan pendapat yang memungkinkan masalah tersebut berkembang menjadi maslah yang baru (Roestiyah, 2008:73). Untuk memenuhi tuntutan kurikulum agar peserta didik turut aktif dalam proses pembelajaran, maka perlu dikembangkan model pembelajaran matematika Knisley berbasis brainstorming.

Tujuan dari pengembangan ini adalah menghasilkan produk hasil pengembangan model pembelajaran matematika Knisley berbasis brainstorming pada materi statistika untuk SMA kelas X. Model pembelajaran beserta sistem pendukungnya dirancang untuk meningkatkan aktivitas dari peserta didik dalam proses pembelajaran matematika, sehingga peserta didik dapat langsung terlibat dalam proses pembelajaran 


\section{KAJIAN TEORI \\ Model Knisley}

Model pembelajaran matematika Knisley lebih dikenal dengan sebutan "A Four-Stage of Mathematical Learning" merupakan model pembelajaran matematika yang dikembangkan oleh Dr. Jeff Knisley. Empat tahapan dalam model pembelajaran ini adalah a) konkret-reflektif pendidik bertindak sebagai narasumber sedangkan peserta didik belum bisa membedakan konsep lama dan konsep baru yang akan dipelajari, b) konkret-aktif yakni pendidik bertindak sebagai pembimbing dan motivator sedangkan peserta didik mencoba untuk membedakan konsep lama dan baru yang dipelajarinya, c) abstrak-reflektif yakni pendidik bertindak sebagai narasumber, sedangkan pada tahap ini peserta didik menbutuhkan penjabaran secara runtut dari suatu penyelesaian masalah, d) abstrakaktif yakni pendidik bertindak sebagai pelatih sedangkan peserta didik menyelesaikan masalah dengan konsep yang telah mereka ketahui (Knisley 2003:11).

Menurut Smith (dalam Mulyana, 2009:45) menjelaskan empat ciri utama pendekatan pembelajaran matematika yaitu peserta didik belajar dalam kelompok kecil, bahan ajar disususn berdasarkan hirarki matematika, menyediakan media pembelajaran, dan akivitas belajar mulai dari konkret-abstrak. Model pembelajaran matematika Knisley cenderung berorientasi pada deep approach dari Smith (Asih, 2013:29).

\section{Metode Brainstorming}

Menurut Roestiyah (2008:73) metode brainstorming merupakan teknik mengajar yang dilaksanakan oleh pendidik dengan cara melontarkan masalah ke kelas, kemudian peserta didik menjawab, menyatakan pendapat, atau memberikan pendapat sehingga memungkinkan masalah berkembang menjadi masalah baru.

Senada dengan hal tersebut Mukrimaa (2014:100) menyatakan bahwa tujuan dari metode brainstorming ini adalah untuk membuat kompilasi pendapat, informasi, pengalaman semua peserta didik baik itu yang sama maupun yang berbeda. Sehingga dapat dismpulkan bahawa metode brainstorming merupakan metode curah pendapat dengan cara pendidik melontarkan masalah ke dalam kelas, dimana prinsip utamanya adalah penundaan kritik terhadap pendapat, informasi, dan pengalaman dari semua peserta didik terhadap masalah yang diberikan pendidik.

\section{Model Pembelajaran Knisley Berbasis Brainstorming}

Model pembelajaran matematika Knisley berbasis brainstorming merupakan kerangka konseptual yang melukiskan proses pembelajaran dengan enam tahap yaitu konkret-reflektif, konkretaktif, abstrak-reflektif, abstrak-aktif, verifikasi-aktif, dan konklusi-aktif dalam mengorganisasi aktivitas pendidik, peserta didik, dan lingkungan belajarnya untuk mencapai tujuan pembelajaran. Sistem sosial yang terbentuk dari model ini adalah interaksi peserta didik dan peserta didik, peserta didik dengan pendidik, serta dengan lingkungan belajaranya. Sedangkan ada tiga prinsip reaksi dari model pembelajaran ini yaitu pendidik menerima semua gagasan dari peserta didik, pendidik menjadi pembimbing, dan pendidik perlu menekankan bahwa perbedaan pendapat merupakan hal yang wajar. Sistem pendukung model ini adalah LKS, LTS, soal evaluasi, dan juga RPP. Dampak Instruksional dari implementasi model pembelajaran ini adalah kemampuan kognitif dalam hal prestasi akademik, sedangkan dampak pengiringanya adalah lebih kepada afektif dan psikomotoriknya yaitu berupa pembentukan sikap disiplin, percaya diri, demokratis, toleransi, dan kerjasama.

\section{METODE PENGEMBANGAN Jenis Penelitian}

Jenis dari penelitian ini adalah penelitian pengembangan (research and development). Tahaptahap pengembangan model pembelajaran matematika Knisley berbasis brainstorming ini mengacu pada tahap-tahap pengembangan model yang dikemukakan oleh Plomp (1999:15) yang hanya sampai 4 tahap, yaitu: (a) preliminary investigation (pengkajian awal), (b) design (perancangan), (c) realisation (realisasi), dan (d) test, evaluation, and revision (tes, evaluasi, dan revisi). Sedangkan komponen-komponen yang tercakup dalam model tersebut mengacu kepada model pembelajaran yang dikemukakan Joyce dan Weil (2009:104-117), yaitu: (a) sintaks, (b) sistem sosial, (c) prinsip reaksi, (d) sistem pendukung, dan (e) dampak instruksional dan dampak pengiring. Sedangkan kriteria kualitas dari model pembelajaran matematika Knisley berbasis brainstorming yang dikembangkan ini 
mengacu pada Nieveen (1999) yaitu valid, praktis, dan efektif. Akan tetapi dalam pengembangan model pembelajaran matematika Knisley berbasis brainstorming ini haya menilai kevalidan, dan kepraktisannnya saja sesuai dengan kriteria yang ada pada Nieveen (1999).

Penelitian ini dilaksanakan di Kota Malang, tepatnya di SMA Negeri 3 Malang dan SMA Negeri 7 Malang untuk mengambil data analisis kebutuhan awal. Uji coba dilaksanakan di kelas X IPA SMA Negeri 3 Malang tahun 2014/2015.

\section{Prosedur Penelitian}

Adapun tahapan atau prosedur pelaksanaan penelitian pengembangan model pembelajaran matematika Knisley berbasis brainstorming adalah sebagai berikut:

\section{a. Fase Investigasi Awal (Preliminari Investigation)}

Tujuan dari fase ini adalah menganalisis masalah dan kebutuhan yang ada dalam pengembangan model pembelajaran matematika Knisley berbasis brainstorming. Untuk mengembangan model pembelajaran ini perlu dilakukan identifikasi dan kajian terhadap teori-teori yang mendukung pengembangan model.

\section{b. Fase Perancangan (Design)}

Pada tahap ini disusun secara garis besar model pembelajaran matematika Knisley berbasis brainstorming. Bersamaan dengan hal ini disusun pula sistem pendukung dari pengembangan model pembelajaran matematika Knsiley berbasis brainstorming.

\section{c. Fase Realisasi (Realisation)}

Pada fase ini model pembelajaran matematika Knisley berbasis brainstorming dan sistem pendukungnya sudah dibuat secara untuk menjadi draf I produk hasil pengembangan model pembelajaran matematika Knisley berbasis brainstorming.

\section{d. Fase Tes, Evaluasi, dan Revisi (Tes, Evaluation, and Revision)}

Fase ini ditujukan untuk mendapatkan data. Kegiatan yang dilakukan pada fase ini adalah validasi oleh validator dan uji coba terhadap draf I produk hasil pengembangan model pembelajaran matematika Knsiley berbasis brainstorming. Draf I yang dihasilkan dikonsultasikan dengan dosen pembimbing untuk selanjutnya divalidasi oleh validator ahli dan praktisi. Berdasarkan hasil validasi tersebut dilakukan revisi terhadap hasil pengembangan model pembelajaran matematika Knsiley berbasis brainstorming sesuai dengan saran dan komentar dari para validator dan dihasilkan Draf final produk hasil pengembangan model pembelajaran matematika Knisley berbasis brainstorming.

\section{HASIL DAN PEMBAHASAN}

\section{Hasil Pengembangan Produk}

Hasil pengembangan model pembelajaran matematika Knisley berbasis brainstorming ini meliputi enam komponen yang harus ada dalam model pembelajaran yaitu:

\section{Sintaks}

Sintaks yang dihasilkan dari pengembangan model ini ada enam tahap pembelajaran yaitu: konkret-reflektif, konkref-aktif, abstrak-reflektif, abstrak-aktif, verifikasi-aktif, dan konklusi-aktif.

\section{Sistem sosial}

Pendidik bertangung jawab di awal pada setiap tahap pembelajaran. Pola interaksi yang terjadi dalam model ini adalah interaksi antara pendidik dan peserta didik, peserta didik dengan peserta didik, dan peserta didik dengan lingkungan belajarnya. Secara sederhana sitem sosial model digambarkan sebagai berikut. 


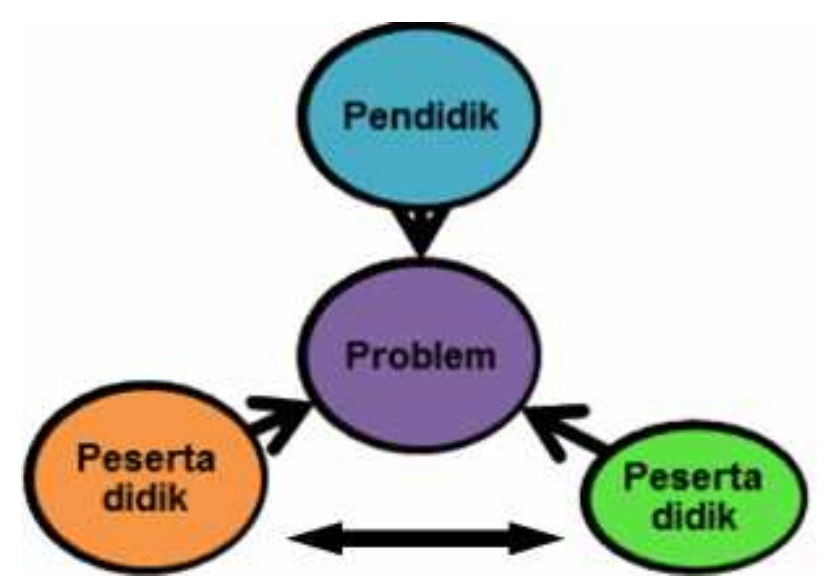

Gambar 1. Pola Interaksi Model Pembelajaran Matematika Knsiley Berbasis Brainstorming

\section{Prinsip reaksi}

Ada tiga prinsip reaksi yang perlu diperhatikan dari model pembelajaran ini yakni: (1) Pendidik menerima respon para peserta didik, (2) Pendidik membimbing peserta didik dalam mencari titik temu dari perbedaan pendapat, dan (3) Pendidik perlu menekankan bahwa perbedaan pendapat merupakan hal yang wajar.

\section{Sistem Pendukung}

Sistem pendukung dari pengem-bangan model pembelajaran matematika Knisley berbasis brainstorming ini ada beberapa yaitu: (1) LKS, (2) LTS, (3) RPP, (4) Soal Tes Evalusi (rubrik penilaian), dan (5) petunjuk penggunaan model (hasil pengembangan model pembelajaran matematika Knisley berbasis brainstorming.

\section{Dampak Instruksional dan Dampak Pengiring}

Dampak instruksional dari pengem-bangan model pembelajaran matematika Knisley berbasis brainstorming ini berupa kemampuan kognitif dari peserta didik dalam bidang akademik.

Dampak pengiring dari implementasi model pembelajaran matematika Knisley berbasis brainstorming ini adalah toleransi, disiplin, kerjasama, kepercayaan diri, dan sikap demokratis untuk bisa menerima pendapat orang lain.

\section{Telaah Ahli dan User}

Pada uji validasi, dan kepraktisan hasil pengembangan model pembelajaran matematika Knisley berbasis brainstorming dilakukan oleh 3 validator yaitu validator ahli pembelajaran matematika, validator ahli desain \& perancang pembelajaran, dan validator praktisi. Sedangkan untuk kepraktisan dilakukan uji coba produk hasil pengembangan model ke kelas X IPA di SMA Negeri 3 Malang sebanyak 35 peserta didik. Berikut adalah hasil validasi ahli, praktisi, dan user. 
Tabel 1. Analisis Data Kelompok Validasi Ahli, Praktisi, dan User

\begin{tabular}{llcl}
\hline No & \multicolumn{1}{c}{ Validator } & $\kappa$ & \multicolumn{1}{c}{ Keterangan } \\
\hline 1. & $\begin{array}{l}\text { Validator ahli pembelajaran } \\
\text { matematika }\end{array}$ & $\mathbf{3 , 4 0}$ & Valid \\
\hline 2. & $\begin{array}{l}\text { Validator ahli desain \& } \\
\text { perancang pembelajaran }\end{array}$ & $\mathbf{3 , 3 4}$ & Valid \\
\hline 3. & Validator praktisi & $\mathbf{3 , 2 6}$ & Valid \\
\hline 4. & User $\quad \sum X_{i}$ & $\mathbf{3 , 3 5}$ & Sangat praktis \\
\hline & & $\mathbf{1 3 , 3 5}$ & \\
\hline & Rata-rata total $(N K)=\frac{2 x_{1}}{N}$ & $\mathbf{3 , 3 4}$ & $\begin{array}{l}\text { Valid dan } \\
\text { praktis }\end{array}$ \\
\hline
\end{tabular}

Dari Tabel 1 dapat ditampilkan ke dalam bentuk Grafik 1 berikut ini.

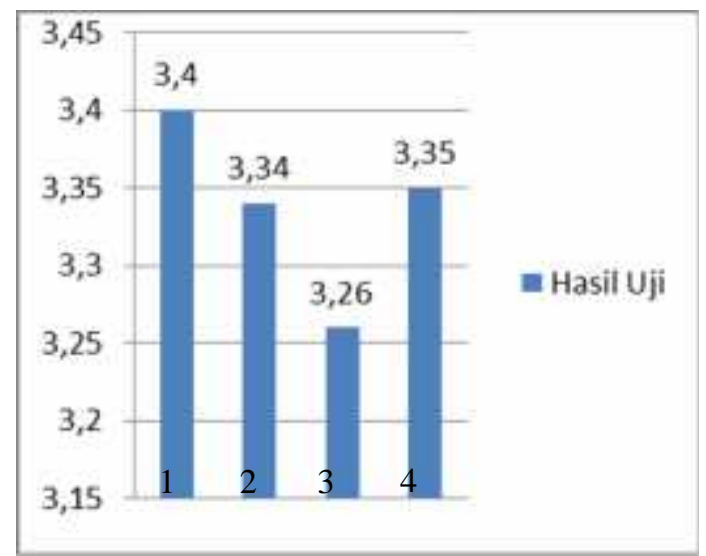

Gambar 1. Hasil Uji Kelompok Validator dan User

Keterangan:

1 : Uji Ahli Pembelajaran Matematika

2 : Uji Ahli Desain \& Perancang Pembelajaran

3 : Uji Praktisi

4 : Uji User

Berdasarkan hasil uji ahli, praktisi, dan user diperoleh skor rata-rata dari ahli pembelajaran matematika yaitu 3,40 yang masuk dalam kategori valid. Untuk ahli desain \& perancang pembelajaran diperoleh skor rata-rata 3.34 yang masuk dalam kategori valid, sedangkan untuk praktisi diperoleh skor rata-rata 3,26 dan masuk dalam kategori valid. Uji user sendiri diperoleh skor rata-rata 3,35 yang masuk dalam kategori sangat praktis. Sehingga rata-rata keseluruhan dari uji validitas dan kepratisan hasil pengembangan model pembelajaran matematika Knisley berbasis brainstorming diperoleh skor rata-rata 3,34 yang masuk dalam kategori valid dan sangat praktis. Dengan demikian hasil pengembangan model pembelajaran matematika Knisley berbasis brainstorming dapat digunakan dalam pembelajaran pada kelompok yang lebih luas. 


\section{Pembahasan}

Menurut Borg and Gall (dalam Setyosari, 2012:215) menyebutkan bahwa pengembangan merupakan suatu proses yang dipakai untuk mengembnagkan dan memvalidasi produk pendidikan. Research \& Develompment, dalam penelitian pengembangan ini adalah pengembangan model pembelajaran. Model pembelajaran merupakan gambaran suatu lingkungan pembelajaran yang meliputi perilaku pendidik dalam membantu peserta didik memperoleh informasi, skill, gagasan, dan peningkatan cara berfikir (Joyce \& Weil, 2009:30). Produk yang akan dihasilkan dari pengembangan model pembelajaran matematika ini adalah desain model pembelajaran dan desain perangkat pembelajarannya.

Hasil pengembangan model pembelajaran matematika Knisley berbasis brainstorming ini dinilai oleh ahli pembelajaran matematika, ahli desain \& perancang pembelajaran, praktisi/pendidik matematika, dan user. Analisis data validasi produk hasil pemgembangan model pembelajaran matematika Knisley berbasis brainstorming materi statistika untuk SMA kelas X masuk kedalam kategori valid dan siap untuk digunakan. Rincinan hasil analisisnya adalah sebagai berikut: (a) validasi ahli pembelajaran matematika skor rata-ratanya adalah 3,40 masuk kedalam kategori valid dan siap digunakan, (b) validasi ahli desain \& perancang pembelajaran dengan skor rata-ratanya adalah 3,34 masuk ke dalam kategori valid dan siap digunakan, (c) validasi praktisi dengan skor ratarata 3,26. Dari ketiga validator diperoleh skor kelompok validator yaitu 3,33 yang masuk ke dalam kategori valid dan siap digunakan. Penilaian kepraktisan dari uji user diperoleh skor rata-rata 3,35 yang termasuk ke dalam kategori sangat praktis.

Berdasarkan hasil uji coba peserta didik memberikan komentar terkait penerapan model pembelajaran matematika Knisley berbasis brainstorming pada materi statistika untuk SMA kelas X bahwa pembelajaran yang dilakukan asyik, menarik, dan tepat sasaran karena sudah dapat membantu peserta didik dalam memahamkan materi.

Terkait dengan kelebihan dari teori konstruktivistik adalah peserta didik lebih memahami materi pembelajaran, karena mereka terlibat secara langsung dalam proses pembelajaran (Thobroni, 2013:123). Berdasarkan data kualitatif dari uji user proses pembelajaran dengan menggunakan model pembelajaran matematika Knisley berbasis brainstorming sudah mampu untuk memahamkan peserta didik terhadap materi yang dipejari, hal ini dikarenakan model pembelajaran matematika Knisley berbasis brainstorming melibatkan peserta didik secara langsung dalam proses pembelajaran yakni dengan cara memberikan kesempatan peserta didik untuk dapat menyampaikan idea tau gagasan mereka terkait dengan masalah dan pengalaman yang mereka peroleh dalam kehidupan sehari-hari. Maka benar adanya jika proses pembelajaran yang melibatkan peserta didik secara langsung dalam kegiatan pembelajaran, dapat membantu peserta didik untuk memahami materi pembelajaran dan tercipta suasana belajar yang menarik dan tidak membosankan.

Dapat disimpulkan bahwa model pembelajaran matematika Knisley berbasis brainstorming ini layak digunakan sebagai alternatif pendidik dalam memilih variasi model atau metode pembelajaran khususnya untuk kelas X pada materi statistika. Model pembelajaran ini terdiri dari enam tahap pembelajaran matematika yaitu konkret-reflektif, konkret-aktif, abstrak-reflektif, abstrakaktif, verifikasi-aktif, dan konklusi aktif. Dimana peserta didik diberikan kebebasan untuk menyampaikan gagasan atau idenya sehingga peserta didik terlibat langsung dalam proses pembelajaran

\section{PENUTUP}

Produk dalam pengembangan ini adalah berupa hasil pengembangan model pembelajaran matematika Knisley berbasis brainstorming. Pengembangan model ini didasarkan pada kurikulum 2013, yang membahas terkait materi statistika. Adapun model pengembangan yang digunakan adalah model pengembangan Plomp yaitu: preliminary insvestigation, design, realisation, test, evaluation, and revision.

Dalam pemanfaatannya hasil pengembangan model pembelajaran matematika Knisley berbasis brainstorming ini diharapkan mampu menjadi alternative pendidik dalam memilih model pembelajaran dan diharapkan dapat membantu pendidik dalam menyampaikan materi. 


\section{DAFTAR RUJUKAN}

Asih, Nadia Nurmala. 2013. Keefektifan Model Pembelajaran Knisley dengan Metode Brainstorming Berbantuan CD Pembelajaran Terhadap Kemampuan Pemahaman Konsep Siswa Kelas X. Skripsi Tidak Diterbitkan. Semarang: UNS.

Joyce, B \& Weil, M. 2009. Models of Teaching Edisi ke Delapan. Yogyakarta: Pustaka Belajar.

Knisley, J. 2003. A Four-Stage Model of Mathematical Learning. Mathematics Educator, 12(1): 10 halaman, (Online) http://WilsonCoe.uga.edu/DEPT/TME/Issues/v12n1/3knisley.html. diakses 2 Pebruari 2015.

Mukrima, Syifa. 2014. 53 Metode Belajar dan Pembelajaran. Bandung: Universitas Pendidikan Indonesia.

Mulyana, Endang. 2009b. Pengaruh Model Pembelajaran Matematika Knisley Terhadap Peningkatan Pemahaman dan Disposisi Matematika Siswa Sekolah Menengah Atas Program Ilmu Pengetahuan Alam. Disertasi. Bandung: Universitas Pendidikan Indonesia.

Nieveen, Nienke. 1999. Prototyping to Reach Product Quality. P.125-135 from Design Approaches and Tools in Education Training. Van den Akker, Jan et.al. Dordrecht: The Netherland Kluwer Academic Publisher.

Plomp, Tjeerd. 1999. Design Methodology and Develophmental Research in/on Educatio and Training. Netherlands: University of Twente.

Roestiyah \& Soeharto. 2008. Strategi Belajar Mengajar. Jakarta: Bina Aksara.

Setyosari, Punaji. 2013. Metode Penelitian Pendidikan dan Pengembangan. Jakarta: Kencana Prenadamedia Group. 